Digital Press Social Sciences and Humanities

Development of Industrial Work Practices With WorkBased Learning (WBL) in Vocational High Schools

Kamaruzaman, Jalius Jama and Nizwardi Jalinus

Proceeding of The Non-Formal Education International Conference 2020

Alim Harun Pamungkas, Jamaris, Solfema (eds) 


\title{
Development of Industrial Work Practices With Work-Based Learning (WBL) in Vocational High Schools
}

\author{
Kamaruzaman*, Jalius Jama, Nizwardi Jalinus \\ Doctoral Program of Education, Universitas Negeri Padang, Padang Indonesia \\ *e-mail: kzzamzaman73@gmail.com
}

\begin{abstract}
The purpose of this study is to develop models of the implementation of industrial work practices in vocational high schools with work-based learning models that are valid, practical, and effective in improving the quality of fieldwork. This research was conducted in three Vocational High Schools in the Electronics Engineering major with 84 students and 10 supervisors. Data on the quality of fieldwork is obtained through performance observation sheets and assessment of structured task reports during the industrial work practice process. Analysis of the data in this study uses descriptive statistics to get the quality of the interpretation of the validity and practicality of model development and the level of performance achievements of respondents. The results showed that the development of the WBL training model was interpreted to be very valid with a value of 0.95 and very practical with a practicality percentage of $95.67 \%$. In addition, the WBL model is more effective in improving the quality of fieldwork in terms of knowledge, professional attitudes, work mental readiness, and student independence in the model class significantly higher than conventional classes.
\end{abstract}

\section{Keywords}

fieldwork, industrial work practices, work-based learning (WBL)

\section{Introduction}

Industrial revolution 4.0 is a challenge that must be faced in the world of education because technological development is very rapid coupled with the trend of combining automation technology with cyber (Ragulina, Alekseev, Strizhkina, \& Tumanov, 2019; Rohman, Fauzan, \& Yohandri, 2020; Schuh, Gartzen, Rodenhauser, \& Marks, 2015). This condition will have an impact on education including digital automation, collaboration, and flexibility which causes changes in the workings of the younger generation and part of the work that will be replaced by robots (Jalinus, 2011; Schuh et al., 2015). With this condition Vocational High School students as a school that produces graduates who will directly enter the workforce must have the abilities and competencies relevant to industries that will be able to compete tightly (Jalinus, 2011).

Some competencies that must be possessed by students to be ready to work in certain areas of expertise relevant to industry competencies include knowledge competence, professional attitude, work mental readiness, and independence (Siswanto, 2013). From the field survey conducted, the implementation of the industrial work practices activities from start to finish has not been arranged as expected because there is no such binding cooperation between the industrial worlds. In addition, the monitoring carried out on industrial work practices activities has not been effective because there are still many of the supervisors who when monitoring are not seriously communicating with industry instructors related to student work activities in the industry and the progress of competencies that have been learned.

From these problems industrial work practices with work-based learning (WBL) are seen to be the right solution to improve the quality of fieldwork results from aspects of knowledge, professional attitude, work mental readiness, and student independence (Braham \& Pickering, 2007; Fallow \& Weller, 2000; Garnett, 2008; Siswanto, 2013). In this article, researchers review the findings obtained in fieldwork activities. Report some findings on the implementation of Work-Based Learning (WBL) in Vocational High School. 


\section{Methods}

This type of research is Research and Development which is used to produce work-based learning models that are valid and practical and effective in improving the quality of fieldwork in vocational high schools. The instrument used to measure the validity and practicality in this study uses an assessment questionnaire. To test the effectiveness of this study the samples came from three vocational high schools, namely SMK 1 West Sumatra, SMK 1 Padang, and SMK 5 Padang, majoring in Electronics Engineering. The number of student respondents was 84 randomly selected and involving 10 supervisors.

Benchmarks of effectiveness test results in this study are the comparison of the average value of the results of fieldwork between the experimental and control groups. The experimental and control groups came from SMK 1 West Sumatra, SMK 1 Padang, and SMK 5 Padang. The experimental group implementing fieldwork practices uses the WBL model, while the control group uses the conventional model. The value of fieldwork is obtained through the performance observation sheet and the assessment of structured task reports during the industrial work practice process. The value of industrial performance results includes aspects of knowledge, professional attitude, work mental readiness, and student independence. Analysis of the data in this study uses descriptive statistics to obtain the quality of the interpretation of the quality of fieldwork. The interpretation of the quality of fieldwork assessments refers to Table 1.

Table 1 Interpretation of Results of Fieldwork Assessments

\begin{tabular}{llr}
\hline \multicolumn{1}{c}{ Formula } & Mean Score & Classification \\
\hline $\bar{x}>\bar{x},+1,8 \times S_{b i}$ & $\overline{\mathrm{x}}>3,4$ & Very Good \\
$\bar{x}_{i}+0,6 \times S_{b i}<\bar{x} \leq \bar{x}_{i}+1,8 \times S_{b i}$ & $\overline{\mathrm{x}}>2,8-3,4$ & Good \\
$\bar{x}_{i}-0,6 \times S_{b i}<\bar{x} \leq \bar{x}_{i}+0,6 \times S_{b i}$ & $\overline{\mathrm{x}}>2,2-2,8$ & Fair \\
$\bar{x}_{i}-1,8 \times S_{b i}<\bar{x} \leq \bar{x}_{i}-0,6 \times S_{b i}$ & $\overline{\mathrm{x}} \leq 1,6-2,2$ & Poor \\
\hline
\end{tabular}

\section{Discussion}

The results of the validity test of the product in the development of the WBL model for industrial work practices in vocational high schools are considered to be very valid by experts with a coefficient of 0.95 . Whereas the assessment conducted by 10 supervisors who used the WBL model in industrial work practices was considered very practical with a percentage of $95.67 \%$ model implementation. The results of testing the effectiveness of the application of the WBL model to fieldwork practices that are interpreted as a percentage of the achievements of fieldwork in each vocational high school can be seen in Fig. 1 .

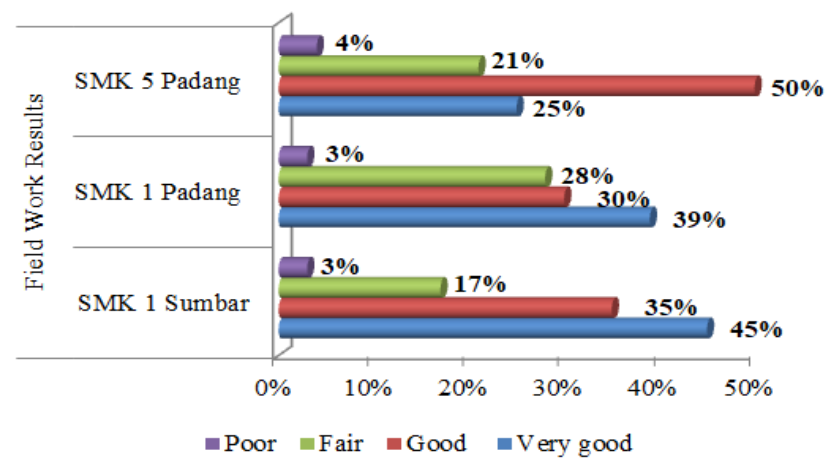

Fig. 1 Percentage of achievements in fieldwork of each sample 
From Fig. 1 it can be explained that in the implementation of the WBL model for fieldwork training in several research samples, researchers found that students of SMK 1 West Sumatra tended to be better able to carry out their tasks independently. This condition was relevant to the achievements of the fieldwork which showed that $45 \%$ of SMK 1 West Sumatra students who follow the fieldwork practices with the WBL model have a very good category. Whereas the good and poor categories are dominated by students of SMK 5 Padang.

Effectiveness test results can be seen from the comparison of the percentage of fieldwork in the experimental group with the controls derived from the study sample. The results of the comparison of the percentage of fieldwork can be seen in Fig. 2.

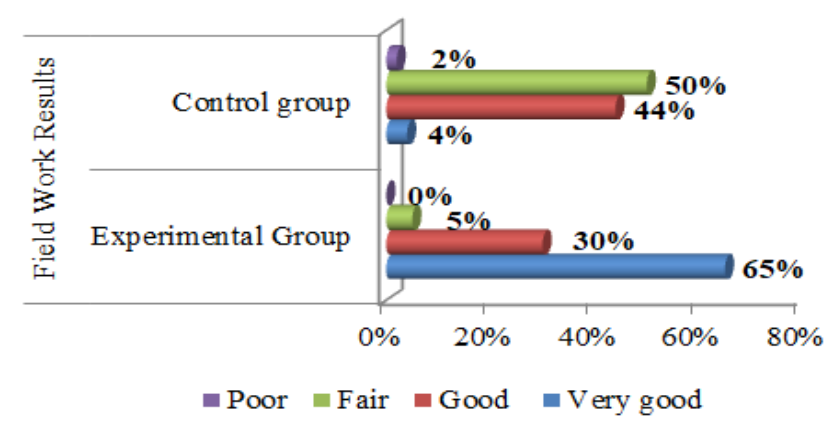

Fig. 2 Percentage of achievements in fieldwork of experiment and control group

Fig. 2 can be explained that the percentage of fieldwork results in the experimental group around $65 \%$ of students have very good grades, while only $4 \%$ of students in the control group have very good grades. From these results, it can be seen that industrial work practices implemented under the WBL model are significantly better than industrial work practices with conventional models. From the observation notes found students are more motivated and responsible in completing the given task, this condition is in line with the opinion of Boud and Solomon (2003) which states that the stages in the WBL model provide learning experiences that enchant students carrying out all the tasks that have been given. The findings in this study are relevant to research Braham, and Pickering (2007) and Garnett (2008) which states that the WBL model is effectively used to improve the quality of fieldwork.

\section{Conclusions}

This study demonstrated the success of the developed WBL model is significantly better than industrial work practices with conventional models in improving the quality of fieldwork. From the results of the validity test, it was found that the WBL model was interpreted to be very valid with a coefficient of 0.95 and was considered to be very practical with a percentage of the feasibility of the model $95.67 \%$.

\section{References}

Boud, D., \& Solomon, N. (2003). Work-based Learning: A New Higher Education. In Great Britain: Marston Book Services Limited. Oxford, Great Britain: Marston Book Services Limited.

Braham, J., \& Pickering, J. (2007). Widening participation and improving economic competitiveness; the dual role of work-based learning within foundation degrees. Proceedings of The Work-Based Learning Futures Conference, 45-52. Buxton, UK.

Fallow, S., \& Weller, G. (2000). Transition from student to employee: A work-based programme for 'graduate apprentices' in small to medium enterprises. Journal of Vocational and Education Training, 52(4), 665685 . 
Garnett, J. (2008). Recognizing and enhancing the quality of university work-based learning program. Proceedings of the Work-Based Learning Futures II Conference, 32-38.

Jalinus, N. (2011). Pengembangan pendidikan teknologi dan kejuruan dan hubungan dunia kerja. Jurnal Pendidikan Vokasi, 1(1), 25. https://doi.org/10.21831/jpv.v1i1.5707

Ragulina, Y. V., Alekseev, A. N., Strizhkina, I. V., \& Tumanov, A. I. (2019). Methodology of criterial evaluation of consequences of the industrial revolution of the 21 st century. In Industry 4.0: Industrial Revolution of the 21st Century (pp. 235-244). Springer, Cham.

Rohman, F., Fauzan, A., \& Yohandri. (2020). Project, Technology and Active (PROTECTIVE) Learning Model to Develop Digital Literacy Skills in the 21st Century. IJSTR, 9(1), 12-16.

Schuh, G., Gartzen, T., Rodenhauser, T., \& Marks, A. (2015). Promoting Work-based Learning through INDUSTRY 4.0. Procedia CIRP, 32, 82-87. https://doi.org/10.1016/j.procir.2015.02.213

Siswanto, B. T. (2013). Model penyelenggaraan work-based learning pada pendidikan vokasi Diploma III Otomotif. Jurnal Pendidikan Vokasi, 2(1), 11-26. https://doi.org/10.21831/jpv.v2i1.1013 